medRxiv preprint doi: https://doi.org/10.1101/2020.05.10.20097329; this version posted May 13, 2020. The copyright holder for this preprint (which was not certified by peer review) is the author/funder, who has granted medRxiv a license to display the preprint in perpetuity.

It is made available under a CC-BY-NC-ND 4.0 International license .

\title{
A Continuously Active Antimicrobial Coating effective against Human Coronavirus 229E
}

Luisa A. Ikner, Jason R. Torrey, Patricia M. Gundy, and Charles P. Gerba

Department of Environmental Science

Center for Water, Environment and Sustainable Technology

University of Arizona

Tucson, AZ 85721

Running title: Antiviral coating

Correspondence: gerba@ag.arizona.edu

\begin{abstract}
The disinfection of high-contact surfaces is seen as an infection control practice to prevent the spread of pathogens by fomites. Unfortunately, recontamination of these surfaces can occur any time after the use of common disinfectants. We recently reported on a novel continuously active antimicrobial coating which was shown to reduce the spread of healthcare acquired infections in hospitals. We evaluated a modified coating that demonstrated a residual efficacy against viruses. The coated surfaces were found to be effective against human coronavirus (HCoV) 229E, reducing the concentration of these viruses by greater than $90 \%$ in 10 minutes and by greater than $99.9 \%$ after two hours of contact. The coating formulation when tested in suspension yielded a greater than $99.99 \%$ reduction of $\mathrm{HCoV} 229 \mathrm{E}$ within ten minutes of contact. This outcome presents an opportunity for controlling the transmission of COVID-19 from contaminated fomites.
\end{abstract}

Keywords: anti-viral coating; infection prevention, coronavirus, continuous acting 
medRxiv preprint doi: https://doi.org/10.1101/2020.05.10.20097329; this version posted May 13, 2020. The copyright holder for this preprint (which was not certified by peer review) is the author/funder, who has granted medRxiv a license to display the preprint in perpetuity.

It is made available under a CC-BY-NC-ND 4.0 International license .

Fomites are inanimate surfaces that may harbor both enteric and respiratory human pathogenic viruses (Boone and Gerba, 2007). Surface disinfection reduces levels of infectious viruses, thereby lowering the potential for their spread in commercial and healthcare facilities, as well as residential environments (Sifuentes et al, 2014; Beamer et al, 2015; Sassi et al, 2015; Reynolds et al 2016, 2019). Unfortunately, recontamination of these surfaces can occur at any time following the use of common liquid disinfectants that are generally wiped dry from surfaces following treatment. Several self-disinfecting surfaces capable of inactivating deposited pathogens have been developed during recent years (Querido et al, 2019). We recently reported on a novel continuously active antimicrobial coating that was shown to reduce the spread of hospital acquired infections in clinical settings (Ellingson et al, 2020; Tamimi et al, 2014). The manufacturer recently developed a second generation of this technology that was designed to provide additional anti-viral action. The purpose of this study was to assess the efficacy of this technology against a coronavirus. Coronavirus 229E, one of the agents of the common cold was used in this study.

\section{Methods}

\section{Sample preparation:}

The antimicrobial coated surfaces with SurfaceWise ${ }^{\mathrm{TM}}$ (a quaternary ammonium polymer coating) were kindly prepared and supplied by Allied BioScience, Inc (Dallas, Texas). Stainless steel coupons (annealed 304) measuring 2" x 2" were cleaned with acetone, sterilized by autoclaving, and arranged on a panel for spraying. A robotic slide was equipped with an electrostatic sprayer, with coating coverage monitored by an XRF (X-Ray Fluorescence Spectroscopy) spectrometer analyzer to ensure application of a uniform coating. After the desired coating thickness was reached, the coupons were removed from the panel and the coating 
medRxiv preprint doi: https://doi.org/10.1101/2020.05.10.20097329; this version posted May 13, 2020. The copyright holder for this preprint (which was not certified by peer review) is the author/funder, who has granted medRxiv a license to display the preprint in perpetuity.

It is made available under a CC-BY-NC-ND 4.0 International license .

was cured overnight. Evenness of coating coverage was again confirmed using a hand-held XRF spectrometer.

\section{Preparation of the test virus:}

Human coronavirus 229E (HCoV) (ATCC VR-740), an enveloped respiratory virus, was propagated and assayed in the human lung fibroblast MRC-5 cell line (ATCC CCL-171).

Infected cells were subjected to three freeze-thaw cycles after cytopathogenic effects (CPE) were observed in the monolayer to release the viruses, and the cell lysates were centrifuged at $1000 \mathrm{x}$ $\mathrm{g}$ for 10 minutes to pellet the cell debris for disposal. The viruses in the supernatant then underwent a polyethylene glycol [9\% (w/v), MW 8000] extraction with $0.5 \mathrm{M}$ sodium chloride, with mixing overnight at $4{ }^{\circ} \mathrm{C}$. After centrifugation at $10,000 \mathrm{x}$ f for $30 \mathrm{~min}$, the pelleted virus was resuspended in 0.01 M phosphate buffered saline (PBS; pH 7.4) (Sigma, St. Louis, MO) to approximately $5 \%$ of the original virus suspension volume. The HCoV 229E stocks were then aliquoted and stored at $-80^{\circ} \mathrm{C}$.

HCoV 229E viral stocks were enumerated on MRC-5 cells seeded into 96-well cell culture trays using the TCID $_{50}$ (tissue culture infectious dose at the $50 \%$ endpoint) technique as described by Payment and Trudel (1993). This technique determines the dilution at which $50 \%$ of the wells show cytopathogenic effects. Taking the inverse log of this dilution gives a titer of the virus per $\mathrm{ml} \mathrm{TCID} 50$. The minimum detection for the method described herein was 3.7 viruses per ml.

\section{Test procedures:}

The American Society of Testing and Materials (ASTM) Method E1153 was used to assess the performance of the anti-viral coating. ASTM E1153 is a quantitative method used to evaluate the efficacy of sanitizers on pre-cleaned inanimate, nonporous, non-food contact surfaces. Per the 
medRxiv preprint doi: https://doi.org/10.1101/2020.05.10.20097329; this version posted May 13, 2020. The copyright holder for this preprint (which was not certified by peer review) is the author/funder, who has granted medRxiv a license to display the preprint in perpetuity.

It is made available under a CC-BY-NC-ND 4.0 International license .

method, products are evaluated against a representative Gram-negative and Gram-positive organism with a maximum contact time of 5 minutes. This method was modified for use in the current study to assess the efficacy of SurfaceWise2 applied to stainless steel coupons against human coronavirus 229E. Coated stainless steel coupons were held under ambient conditions for 14 days after treatment. On the day of testing, $0.1 \mathrm{~mL}$ of viral suspension (no soil load) was inoculated onto the coated stainless steel carriers and incubated for a contact time of 120 minutes at room temperature. At conclusion of the contact time, a cotton-tipped swab pre-dipped in Letheen Broth Base (LBB) (Hardy Diagnostics, Santa Martin, CA) was used to neutralize the test material and to extract remaining infectious viruses from the test surface. The swab was then placed into a tube containing $1 \mathrm{~mL}$ of $\mathrm{LBB}$, and vortexed vigorously to release the viruses. The entirety of the virus suspension was immediately passed through a Sephadex G-10 (Sigma, St. Louis, MO) gel filtration column for secondary neutralization, and to decrease cytotoxic effects on MRC-5 host cell monolayers. Columns were centrifuged for 5 minutes at 4,000 x g to extract the liquid. Appropriate 1:10 dilutions of neutralized control and test extracts were made using Eagle Minimal Essential Media (MEM) (Mediatech, Manassas, CA), followed by plating onto MRC-5 monolayers prepared in 96-well trays in replicates of six per dilution $(0.050 \mathrm{~mL}$ per well). The efficacy of the test substance was determined by comparing the amount of reduction in virus titer between the control and test conditions and calculating the $\log _{10}$ reduction. The test procedure is shown in Figure 1.

Antiviral efficacy of SurfaceWise 2 was further evaluated in liquid form using the ASTM E1052 Standard Test Method. The test virus was prepared as described previously, and $0.1 \mathrm{~mL}$ of the virus stock suspension were added to $0.9 \mathrm{~mL}$ of the test substance (Ready-to-Use liquid) followed by a brief vortex and contact time of 10 minutes at room temperature. A separate tube 
containing $0.9 \mathrm{~mL}$ of MEM was used as a control. At conclusion of the contact time, $0.1 \mathrm{~mL}$ of test suspension was added to $0.9 \mathrm{~mL}$ Letheen Base Neutralizing Broth (Hardy Diagnostics, Santa Martin, CA). After brief vortexing, the total volume of the neutralized test suspension was passed through a Sephadex G-10 gel filtration column followed by gel filtration as previously described. Appropriate dilutions (1:10) of neutralized control and test conditions were made in MEM and plated in replicates of four per dilution on MRC-5 cell monolayers prepared in 24well trays $(0.1 \mathrm{~mL}$ pre replicate well). Viral titers in the Control and Test Suspensions were calculated using the Spearman-Karber Method. The efficacy of the test substance is determined by calculating the $\log _{10}$ reduction of infectious viruses remaining after exposure to the test product for the 10-minute contact time relative to the infectious viral titer in the control suspension. 
medRxiv preprint doi: https://doi.org/10.1101/2020.05.10.20097329; this version posted May 13, 2020. The copyright holder for this preprint (which was not certified by peer review) is the author/funder, who has granted medRxiv a license to display the preprint in perpetuity.

It is made available under a CC-BY-NC-ND 4.0 International license .

Figure 1. Diagram of the procedure

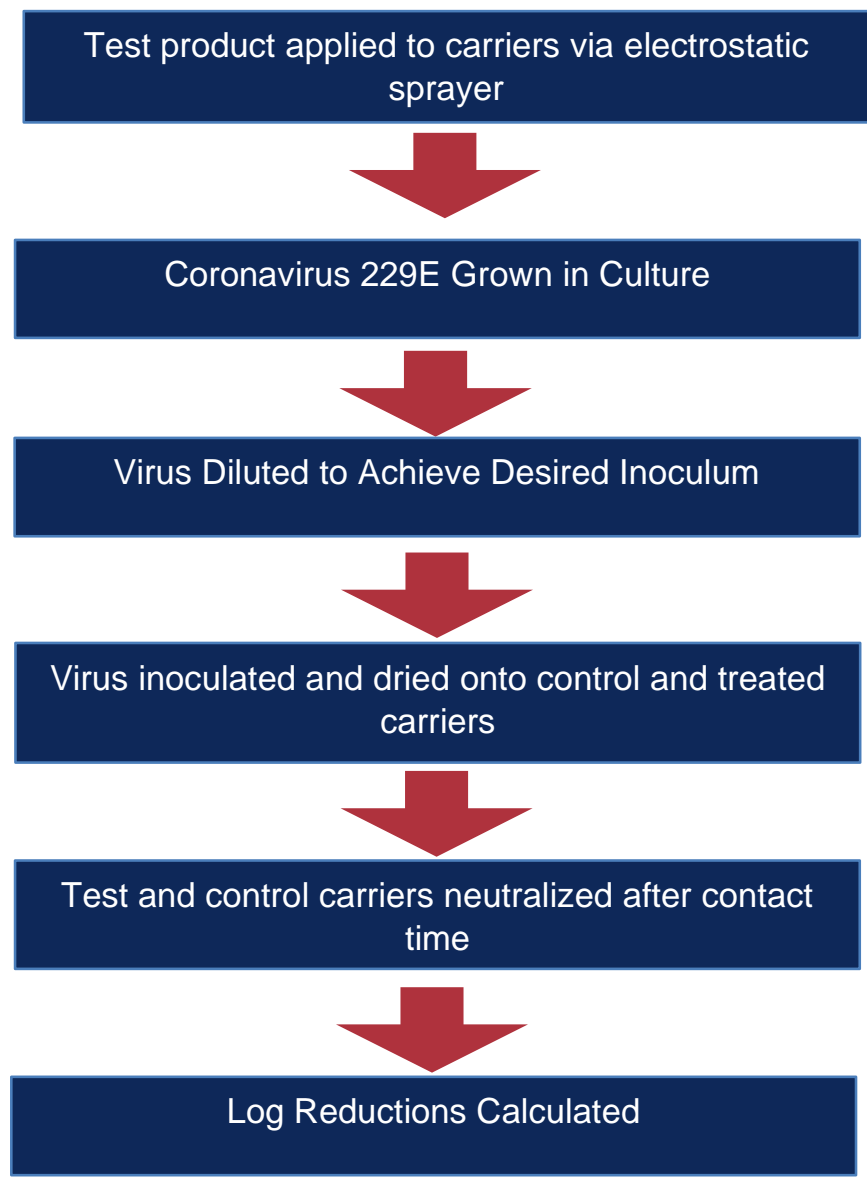

\section{Results:}

The results shown in Table 1 demonstrate a $1.34 \log (>90 \%)$ reduction of the virus in ten minutes compared to the control untreated surface and a greater that 3.99 logs (>99.99\%) within two hours. 
Table 1. Inactivation of human coronavirus 229E on SurfaceWise2-treated vs. nontreated stainless steel (SS) surfaces

\begin{tabular}{|c|c|c|c|c|}
\hline Surface Type & $\begin{array}{c}\text { Contact } \\
\text { Time } \\
\text { (minutes) }\end{array}$ & $\begin{array}{c}\text { Recovered } \\
\text { Viral Titer } \\
\text { (TCID50/ ml) }\end{array}$ & $\begin{array}{c}\text { Mean Recovered } \\
\text { Viral Titer } \\
\text { (TCID50/ ml) }\end{array}$ & $\begin{array}{c}\log _{10} \\
\text { Reduction }\end{array}$ \\
\hline $\begin{array}{c}\text { Untreated } \\
\text { SS Control }\end{array}$ & 10 & $\begin{array}{l}9.28 \mathrm{E}+04 \\
4.31 \mathrm{E}+04 \\
2.94 \mathrm{E}+04\end{array}$ & $5.51 \mathrm{E}+04$ & N/A \\
\hline $\begin{array}{c}\text { SurfaceWise2 } \\
\text { SS }\end{array}$ & 10 & $\begin{array}{l}2.94 \mathrm{E}+02 \\
2.94 \mathrm{E}+03 \\
4.31 \mathrm{E}+03\end{array}$ & $2.51 \mathrm{E}+03$ & 1.34 \\
\hline $\begin{array}{c}\text { Untreated SS } \\
\text { Control }\end{array}$ & 120 & $\begin{array}{l}6.32 \mathrm{E}+04 \\
2.94 \mathrm{E}+04 \\
9.28 \mathrm{E}+04 \\
\end{array}$ & $6.18 \mathrm{E}+04$ & N/A \\
\hline Treated & 120 & $\begin{array}{l}<6.32 \\
<6.32 \\
<6.32\end{array}$ & $<6.32$ & $>3.99$ \\
\hline
\end{tabular}

$\mathrm{NA}=$ not applicable

Table 2 also demonstrate that liquid form of ready-to-use SurfaceWise ${ }^{\mathrm{TM}}$ reduced coronavirus titer by $>4.7 \log _{10}(>99.99 \%)$.

2. Inactivation of human coronavirus $229 \mathrm{E}$ in suspension by SurfaceWise2 ${ }^{\mathrm{TM}}$

\begin{tabular}{|c|c|c|c|c|}
\hline Suspension & $\begin{array}{c}\text { Contact } \\
\text { Time } \\
\text { (minutes) }\end{array}$ & $\begin{array}{c}\text { Viral Titer } \\
\text { (TCID50/ml) }\end{array}$ & $\begin{array}{c}\text { Mean Viral Titer } \\
\text { (TCID50/ml) }\end{array}$ & $\begin{array}{c}\text { Log } \\
\text { Reduction }\end{array}$ \\
\hline MEM & 10 & $\begin{array}{l}1.78 \mathrm{E}+06 \\
1.78 \mathrm{E}+06\end{array}$ & $1.75 \mathrm{E}+06$ & N/A \\
\hline Control) & 10 & $\begin{array}{c}<3.16 \mathrm{E}+01 \\
<3.16 \mathrm{E}+01\end{array}$ & $<3.16 \mathrm{E}+01$ & $>4.75$ \\
Antimicrobial & \multicolumn{2}{|c|}{ Ready-to-use } & 10.75 \\
\hline
\end{tabular}


medRxiv preprint doi: https://doi.org/10.1101/2020.05.10.20097329; this version posted May 13, 2020. The copyright holder for this preprint (which was not certified by peer review) is the author/funder, who has granted medRxiv a license to display the preprint in perpetuity.

It is made available under a CC-BY-NC-ND 4.0 International license .

\section{Discussion:}

Antiviral coatings offer the advantage of rendering viruses noninfective following contact with a treated surface. Antimicrobial-coated surfaces are not meant to substitute for regular cleaning and disinfection of surfaces, but rather offer an additional barrier to reduce human exposure to infectious viruses from fomites. During the fall season, respiratory viruses such as influenza (Boone and Gerba, 2005) and parainfluenza (Boone and Gerba, 2010) can be found on third or more of common high-touch fomites, and therefore serve as an exposure route for the transmission of these and other infectious agents. It has been found that the contamination of a push plate door entrance into an office building can lead to contamination of $50 \%$ of the commonly-touched surfaces and hands of office workers within four hours (Reynolds et al, 2016). Interventions that employ disinfecting wipes have been shown to reduce the probability of infection in office settings (Beamer et al, 2015). Antimicrobial coatings could provide an additional novel mean of protection in reducing the spread of coronaviruses in indoor environments and public places where there is continuous contamination.

\section{References:}

Beamer P.I., Plotkin K.R., Gerba C.P., Sifuentes L.Y., Koenig D.W., and Reynolds K.A. 2015. Modeling of human viruses on hands and risk of infection in an office workplace using microactivity data. J. Occup. Environ. Hyg. 12:266-75.

Boone, S. A. and C. P. Gerba. 2005. The occurrence of influenza A virus on household and day care center fomites. J. Infect. 51:102-109.

Boone, S. A. and C. P. Gerba. 2007. Significance of fomites in the spread of respiratory disease and enteric viral disease. Appl. Environ. Microbiol. 73:1687-1696.

Boone, S. A. and C. P. Gerba. 2010. The prevalence of human parainfluenza virus 1 on indoor office fomites. Food Environ. Virol. 2:41-46.

Ellingson, K. D., Pogreba-Brown, C. P. Gerba and S. P. Elliott. 2020. Impact of a novel antimicrobial surface coating on health care-associated infections and environmental bioburden at 2 urban hospitals. Clin. Infect. Dis., https://doi.org/10.1093/cid/ciz1077. 
medRxiv preprint doi: https://doi.org/10.1101/2020.05.10.20097329; this version posted May 13, 2020. The copyright holder for this preprint (which was not certified by peer review) is the author/funder, who has granted medRxiv a license to display the preprint in perpetuity. It is made available under a CC-BY-NC-ND 4.0 International license .

Payment, P., and Trudel, M. (1993). Methods and Techniques in Virology. New York, NY: Marcel Dekker, Inc.

Querido, M. M., L. Neves, C. C., P. Neves, C. S. Pereira, and J. P. Teixeria. 2019. Selfdisinfecting surfaces and infection control. Colloilds Surfaces B:Biointerfaces 178:8-21.

Reynolds K.A., P. I. Beamer, K. R. Plotkin, L. Y. Sifuentes, D. W. Koenig, and C. P. Gerba. 2016. The Healthy Workplace Project: Reduced Viral Exposure in an Office Setting. Arch. Environ. Occup. Health. 71:157-162.

Reynolds, K. A., J. D. Sexton, T. Pivo, K. Humphrey, R. A. Lesile and C. P. Gerba. 2019. Microbial transmission in an outpatient clinic and impact of an intervention with an ethanolbased disinfectant. Am. J. Infect. Cont. 47:128-132.

Sassi, H. P., L. Y. Sifuentes, D. W. Konig, E. Nichols, J. Clark-Gruel, L. F. Wong, K. McGrath, C. P. Gerba and K. A. Reynolds. 2015. Control of the spread of viruses in a long term care facility using hygiene protocols. Am J. Infect. Contr. 43:702-706.

Sifuentes, L. Y., D. W. Koenig, R. L. Phillips, K. A. Reynolds and C. P. Gerba. 2014. Use of hygiene protocols to control the spread of viruses in a hotel. Food Environ. Virol. 6:175-181.

Tamimi, A. K, Caslino, S. and C. P. Gerba. 2014. Long-term efficacy of a self-disinfecting coating in an intensive care unit. Am. J. Infect. Contr. 42:1176-1181.

Conflict of interest: This project was funded by Allied Biosciences to the University of Arizona, whose researchers participated in the study design. The conduct of the study, analysis, and presentation of the results as well as the decision to publish were solely determined by the authors without influence by the funding source. 